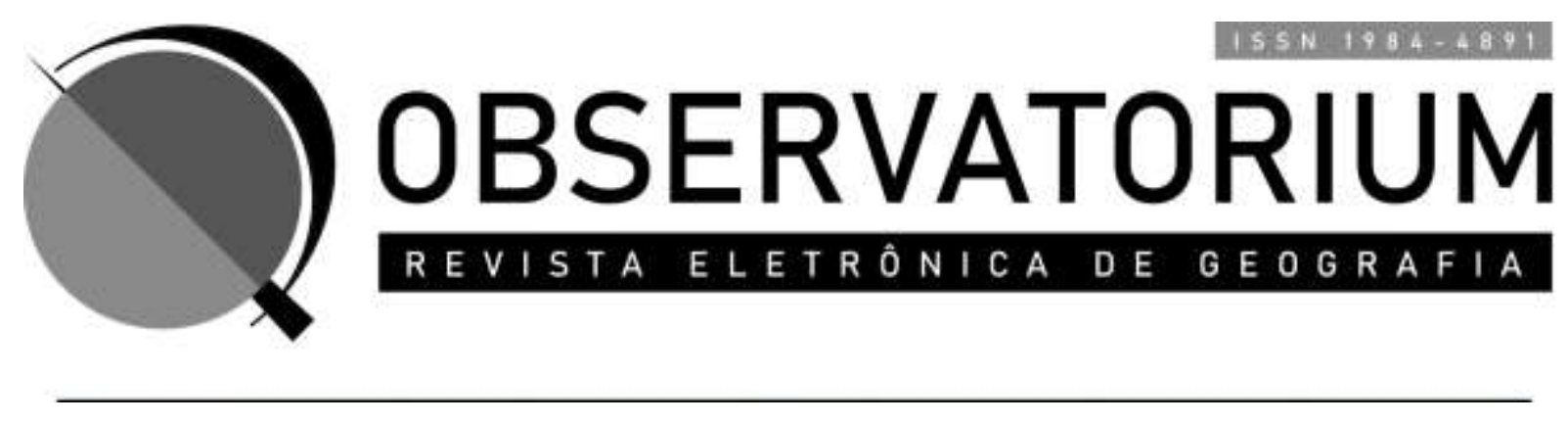

\title{
O CIBERESPAÇO COMO PRODUTO E (RE)PRODUTOR DO ESPAÇO GEOGRÁFICO1
}

\author{
THE CYBERSPACE AS A PRODUCT AND A (RE)PRODUCER OF THE GEOGRAPHIC SPACE
}

Henrique Caetano Vian²

\section{RESUMO}

Perante às mais diversas entidades organizadoras do mundo contemporâneo, como os Estados e as grandes corporações, a instrumentalização das redes nos bastidores do crescente fluxo tecnológico se dá como chave para o domínio e controle de incontáveis aspectos sociais, culturais, econômicos e políticos na atualidade. O ciberespaço, enquanto produto e (re)produtor do espaço geográfico se caracteriza como um instrumento, por excelência, do poder. Mas para quais fins ele é utilizado? E quais são seus efeitos, no que diz respeito à transformação do espaço geográfico? Este artigo visou destacar o ciberespaço enquanto produto imaterial das condições materiais da realidade, capaz de reconfigurar a própria materialidade que o gerou, sob interesses específicos. Para a compreensão deste processo, em um primeiro momento objetivouse abordar o contexto e o processo espaço-temporal da produção do ciberespaço por meio da origem e do desenvolvimento dele ao longo das últimas décadas. Em sequência, o ciberespaço foi analisado como um produto socioespacial, mas também como um (re)produtor de transformações, dinâmicas e ressignificações no/do espaço geográfico. Por fim, a discussão foi direcionada ao objetivo - urgente - de debater a vulnerabilidade social no espaço (i)material pelo processo de individualização, despersonalização e fragmentação dos indivíduos, potencializado cada vez mais pelas Tecnologias da Informação e Comunicação (TICs).

PALAVRAS-CHAVE: Espaço Virtual; Redes Digitais; Tecnologias da Informação; Material e Imaterial; Geografia.

\footnotetext{
${ }^{1}$ Este trabalho diz respeito à Iniciação Científica desenvolvida por Henrique Caetano Vian no âmbito do PET Programa de Educação Tutorial, do curso de Graduação em Geografia da Universidade Federal de Uberlândia (UFU), sob a orientação da Prof ${ }^{a}$. Dra . Gláucia Carvalho Gomes, do Instituto de Geografia. O período de vigência da pesquisa e da orientação foi de julho/2019 a janeiro/2021. Número de registro DIRPE/PET: 0121/2020.

${ }^{2}$ Graduando em Geografia na Universidade Federal de Uberlândia (UFU). Bolsista do Programa de Educação Tutorial (PET/MEC). E-mail: henriquecvian@gmail.com.
} 


\begin{abstract}
In face of the several organizing entities of the contemporary world, such as the States and the big corporations, the instrumentalization of the networks behind the growing technologic fluxes gives the tools for the dominance and control of countless social, cultural, economic and political aspects in the present. The cyberspace, as a product and a (re)producer of the geographic space characterizes itself as an instrument, for excellence, of power. However, for what purposes is it serve? Furthermore, what are its effects, regarding to the transformation of the geographic space? This article aims to highlight the cyberspace as an immaterial product of the material reality, which is able to reconfigure the very materiality that generated it, under specific interests. For the understanding of its process, the article objectives to approach the context and the spatial-temporal process of the cyberspace's production by its origin and development over the past decades. Subsequently, the cyberspace was analyzed as a socio-spatial product, as well as a (re)producer of transformations, dynamics and resignifications on/in the geographic space as well. Finally, the discussion is directed to the - urgent goal of debating the social vulnerability in the (im)material space by the process of individualization, depersonification and fragmentation of the individuals, which is increasingly empowered by the Informational and Communication Technologies (ICTs).
\end{abstract}

KEYWORDS: Virtual Space; Digital Networks; Information Technologies; Material and Immaterial; Geography.

\title{
INTRODUÇÃO
}

O acelerado desenvolvimento científico e tecnológico vivenciado pela sociedade, especialmente a partir da segunda metade do século XX, trouxe, dentre inúmeras inovações, a evolução e a expansão das Tecnologias da Informação e da Comunicação (TICs). Indubitavelmente, na década de 1990, a Rede Mundial de Computadores, a Internet e os computadores domiciliares, progressivamente, potencializaram os fluxos de comunicação entre os indivíduos e a dinamização do mercado mundial. Estas dinâmicas informacionais teceram novas relações de conexão entre pessoas físicas e jurídicas por todo o globo, de maneira nunca antes experenciada. As TICs imateriais, remotas e “instantâneas" impactaram, diversas vezes transformando, processos sociais, políticos, econômicos e culturais que antes se viam condicionados por barreiras da materialidade (muitas das quais espaciais).

Como destacado por Lévy (1999, p. 13), “durante uma entrevista nos anos 1950, Albert Einstein declarou que três grandes bombas haviam explodido durante o século XX: a bomba demográfica, a bomba atômica e a bomba das telecomunicações”. A referência de Lévy, indicativa da genialidade do autor da Teoria da Relatividade, 
demonstra a perspectiva arguta daqueles que são capazes de apreender processos embrionários que, no caso do terceiro, explodiu sobre o espaço e as relações socioespaciais.

Na ciência geográfica, os estudos populacionais, há décadas, teorizaram o fenômeno do crescimento demográfico, assim como a geopolítica possui vasta bibliografia acerca dos conflitos bélicos mundiais dos séculos passados. Também não são inéditos os estudos acerca dos efeitos das redes informacionais sobre o território. Esse conjunto de estudos, bem como os demais de outros campos geográficos, são indicativos do modo como a reprodução social do espaço encontra-se no cerne da Geografia. Todavia, há um outro campo, desnudado pela explosão da "bomba das telecomunicações" que, se outrora formou uma "nova espacialidade”, há tempos se sobrepõe ao espaço social, reproduzindo-o. Assim, entendo que as reflexões desenvolvidas sobre o ciberespaço e a cibercultura, na ciência geográfica, são preceitos fundamentais para a compreensão do ordenamento socioespacial contemporâneo.

O ciberespaço, enquanto produto de uma conjuntura espaço-temporal (e, portanto, geográfica), demonstra-se como um instrumento imaterial, de caráter fundamental para o suporte de novas relações necessárias à reprodução expandida do capital. Sendo, deste modo, um produto do espaço material, contribui como mediador (e potencializador) de relações que atuam sobre o espaço que o gerou, reelaborando e (re)produzindo uma nova materialidade em permanente reinserção nesse circuito Material-Imaterial-Material'.

Sob tal perspectiva, o que se compreende é que as relações sociais e mercadológicas são potencializadas pelo ciberespaço e, nessa condição, possuem grande influência sobre o espaço geográfico materializado hodierno. Assim, assume-se a importância de compreender o ciberespaço enquanto resultado, mas também como instrumento essencialmente transformador no processo de reordenamento socioespacial que vivenciamos. Em outras palavras, o ciberespaço (como um tipo de espaço imaterial) surge como produto e (re)produtor do espaço geográfico. Sem essa percepção, fenômenos tão atuais de temas clássicos da Geografia - como a decisão da saída da Inglaterra da União Europeia - não são compreendidos em sua complexa totalidade.

Este trabalho objetiva, portanto, compreender o ciberespaço enquanto produto e (re)produtor do espaço geográfico a partir de quatro etapas: a) a abordagem do contexto e do processo espaço-temporal da produção do ciberespaço, por 
intermédio da origem e de seu desenvolvimento ao longo das últimas décadas; b) a análise do ciberespaço enquanto um produto, mas também como um (re)produtor de transformações, dinâmicas e ressignificações no/do espaço geográfico a partir das necessidades de reprodução do capital; c) a atualização da temática perante aos novos mecanismos tecnológicos e suas reconfigurações nas dinâmicas socioespaciais e; d) a discussão da influência do ciberespaço na vulnerabilidade social no espaço (i)material pelos processos de individualização, despersonalização e fragmentação dos sujeitos e dos lugares.

Por fim, torna-se importante salientar que o presente trabalho não visa esgotar o assunto, tendo em vista que esta é uma discussão laboriosa e digna de ampliação bibliográfica. O que se busca aqui, ao assumir a importância do estudo do ciberespaço na ciência geográfica, é reconhecer sua magnitude nas dinâmicas socioespaciais que hoje nos circundam e nos (re)produzem. A partir dessa discussão, almejo promover a reflexão com os leitores que aqui se dispõem e, de certo modo, colocar "mais uma peça" nessa caminhada para que continuemos, coletivamente, discutindo os rumos e perspectivas de uma vertente da Geografia que creio ser passível de profundas e grandiosas análises.

\section{AS TECNOLOGIAS DA INFORMAÇÃO E COMUNICAÇÃO (TICs): O CIBERESPAÇO EM QUESTÃO}

São habituais na Geografia os estudos acerca da globalização e seus desdobramentos em mundo cada vez mais heterogêneo. O século XXI se apresenta, continuamente, como o cenário-temporal dos novos fluxos técnico-científicoinformacionais, promovidos em larga escala a partir da segunda metade do século passado, como estudado por Santos (1996). Dentre os fluxos cada vez mais ampliados, a interconexão mundial das redes informacionais e os dispositivos eletrônicos tramaram um "novo" tipo de espaço imaterial: o ciberespaço.

O neologismo ciberespaço, cunhado por William Gibson e desenvolvido em seu romance cyberpunk intitulado Neuromancer (1984), representa a espécie de um "todo", que é formado por diversos fragmentos (os algoritmos, a conexão, a estrutura eletrônica, e os eus 3) que o sustentam e o dão "vida". Contudo, em sua obra literária,

\footnotetext{
${ }^{3}$ Discussão promovida por Margaret Wertheim em sua obra "Uma história do espaço de Dante à Internet", originalmente publicado em 1999. A autora afirma que a criação desse novo espaço imaterial (o ciberespaço) possui profunda significação psicossocial, tendo em vista que "esse novo domínio digital funciona como um
} 
Gibson classifica o ciberespaço como um "mundo paralelo", dissociado do mundo real, de modo que as experiências virtuais são apreendidas de maneira primária, isto é, surgem primeiro na "camada" imaterial e modificam os contornos da materialidade, tal como evidenciou Israel (2019).

Os diversos dispositivos técnicos pelos quais as informações trafegam sustentam e, também, fazem parte desse ciberespaço. Por exemplo, um computador que faz parte do mundo material e dá suporte ao ciberespaço, se torna também uma das partes "vitais" dele. Este espaço imaterial, então suportado pelo o mecanismo da Internet, caracteriza-se como um "novo espaço" que, mesmo intangível, se configura como (re)produtor da realidade. Conforme afirmou Israel (2019, p. 33), na gênese da era informacional "o computador é um elemento indissociável e a Internet seu mais espraiado resultado". O ciberespaço, deste modo, surge como espaço-instrumental de transformações políticas, econômicas, sociais e culturais, produzindo e (re)produzindo o espaço geográfico de acordo com as necessidades de quem o controla e utiliza. Ainda, de acordo com Israel (2019, p. 21), este espaço virtual define-se "a partir de geometrias de poder que promovem espacialidades verticais ou hierárquicas de um lado e espacialidades horizontais ou distribuídas de outro".

Segundo Pierre Lévy (1999, p. 22), "as tecnologias são produtos de uma sociedade e de uma cultura". Sob essa ótica, torna-se imprescindível retomar o contexto histórico em que a Internet foi criada, para que compreendamos quais condicionantes foram empregadas em tal ato. Como também afirmou Santos (2017, p. 181), as tecnologias "são irreversíveis, na medida em que, em um primeiro momento, são produtos da história, e, em um segundo momento, elas são produtoras da história, já que diretamente participam desse processo".

De acordo com Castells (2007, p. 34), "a Internet nasceu da encruzilhada insólita entre a ciência, a investigação militar e a cultura libertária”. Sua origem está associada ao período da Guerra Fria, mais precisamente ao ano de 1969, desenvolvida pela Advanced Research Project Agency (ARPA), do Departamento de Defesa dos Estados Unidos (DOD). Tal fundação representou uma das variadas estratégias geopolíticas promovidas durante a guerra, as quais visavam a hegemonia do bloco capitalista-ocidental diante do bloco socialista-oriental.

espaço para experiências mentais e jogos complexos". Ainda, Wertheim alega que, nesse sentido, "podemos ver o ciberespaço como uma espécie de res cogitans eletrônica”, isto é, um domínio digital para a mente, para a imaginação, para a representação do "eu". 
Todos os avanços tecnológicos chave, que desembocaram na criação da Internet, são fruto do trabalho de instituições governamentais, grandes universidade e centros de investigação. A Internet não teve a sua origem no mundo empresarial. Era uma tecnologia demasiado arriscada para ser assumida por uma empresa privada. Era esse o caso, sem dúvida, nos anos 6o, época em que as empresas trabalhavam de maneira bastante conservadora nas suas estratégias industriais e financeiras e não estavam dispostas a arriscar capital e a investir recursos humanos em tecnologias visionárias. (CASTELLS, 2007, p. 39-40)

O que inicialmente foi uma projeção tecnológica estatal, a serviço do bloco geopolítico capitalista-ocidental, após sua bem-sucedida fase de implementação e testes ligados à política, progressivamente, tornou-se um mecanismo de reprodução ampliada de poder econômico. Somente a partir da confirmação de um ideal promissor e da garantia de retornos monetários, o mundo empresarial se apropriou das novas Tecnologias da Informação e Comunicação, instrumentalizando-as e submetendo-as aos circuitos de reprodução capitalista da riqueza. Como podemos destacar, poucos anos após o desenvolvimento da Internet, em 1975, foi fundada a prestigiosa Microsoft Corporation, por Bill Gates e Paul Allen, que viria a se tornar a maior empresa de softwares do mundo, presidida por personalidades que figurariam entre os homens mais ricos do planeta na atualidade. 4

Em sua versão contemporânea, a tecnologia se pôs a serviço de uma produção em escala planetária, onde nem o limite dos Estados, nem os dos recursos, nem os dos direitos humanos são levados em conta. Nada é levado em conta, exceto a busca desenfreada do lucro, onde quer que se encontrem elementos capazes de o permiti-lo. (SANTOS, 2017, p. 181)

Retomando a análise, o estudo das redes e os seus impactos na Geografia em escala mundial não são recentes, como já afirmara Dias (2007) e tampouco a preocupação em compreender os efeitos destas sobre a organização do território. A amplificação e o aceleramento dos meios informacionais intensificaram o processo de reordenamento espacial em escala global. Assim, o ciberespaço, potencializado pela invenção da Internet, foi desenvolvido primeiramente pelos Estados e, posteriormente, incorporado pelas grandes corporações mundiais que promoveram sua evolução e redirecionamento. Deste modo, manteve-se como um instrumento de poder valioso e centralizado, capaz de reorganizar o espaço sob os condicionantes de uma lógica hegemônica.

\footnotetext{
${ }^{4}$ Ranqueamento diário das pessoas mais ricas do mundo, pela Revista Forbes. Disponível em: https://www.forbes.com/real-time-billionaires/. Acesso em: 28 mar. 2020.
} 
É fundamental salientar que a invenção da Internet não se sinonimiza ao surgimento do ciberespaço. Neste momento, retoma-se a importante discussão desenvolvida por Douzet (2014) sobre as duas nomenclaturas. De acordo com a autora, estes são elementos interligados, entretanto, distintos. A Internet atua como o suporte para a criação de um espaço e, dessa relação, emerge o ciberespaço (Internet + espaço virtual criado). O ciberespaço, a partir de sua possibilidade de existência é, de acordo com Lévy (1999, p. 94) o "espaço de comunicação aberto pela interconexão mundial de computadores e das memórias dos computadores”. Como afirmou Israel (2019, p. 21), "é a partir desse par de elementos técnicos [computador e Internet] que o espaço virtual, ou ciberespaço, ganha forma".

Segundo Santos (2017), é a partir da unicidade das técnicas, da qual o computador é uma peça central (e, atualmente, outros dispositivos), que surge a possibilidade de existir novas dinâmicas globais. Este, por sua vez, comporta-se como um macrossistema técnico, isto é, sistemas sem os quais outros sistemas técnicos não funcionariam. Ainda com a existência do computador, o sistema técnico da Internet não obteria relações de influência sem a utilização de um espaço para sua atuação, assim como tal espaço imaterial não seria desenvolvido sem as intencionalidades de um espaço material que o produz e instrumentaliza.

Ainda que compreendamos o computador enquanto uma peça central para a existência das dinâmicas globais interconectadas, devemos também compreendê-lo como um artigo além de sua materialidade. Como afirmou Lévy (1999, p. 45):

O computador não é mais um centro, e sim um nó, um terminal, um componente da rede universal calculante. Suas funções pulverizadas infiltram cada elemento do tecnocosmos. No limite, há apenas um único computador, mas é impossível traçar seus limites, definir seu contorno. É um computador cujo centro está em toda parte e a circunferência em lugar algum, um computador hipertextual, disperso, vivo, fervilhante, inacabado: o ciberespaço em si.

Os computadores agora representam não mais somente um item, mas os nós de uma rede tramada em diversos pontos do globo, pelos mais diversos e remotos agentes. A rede se dá como um objeto inacabado, um continuum que se expande irremediavelmente. Ela é construída por diversos processos materiais e imateriais, mas também é capaz desconstruir e reconstruir novos espaços, sejam eles táteis ou não. Como discute Chauí (2006, p. 59),

Computadores controlam armas e operações militares, vôos espaciais, operações espaciais, operações de aeroportos, de bancos e bolsas de valores, 
de sistemas urbanos de tráfego e de segurança, de edifícios denominados 'inteligentes' e de setores inteiros do trabalho industrial e da produção econômica. Estão presentes nos carros de último tipo, nos estabelecimentos comerciais que vendem no atacado e no varejo, nos setores administrativos das instituições públicas e privadas. Encontram-se nas escolas e fazem parte do sistema de ensino e aprendizado dos países economicamente poderosos. Estão presentes nas editoras e produtoras gráficas, nos escritórios de engenharia, arquitetura e advocacia; nos consultórios médicos e hospitais; nas produtoras cinematográficas, fonográficas, televisivas e radiofônicas. Tornaram-se instrumentos de trabalho de escritores, artistas, professores e estudantes, além de operarem como banco de dados para as informações na vida cotidiana, como correio, lazer e entretenimento.

Mas há outros aspectos do impacto desse equipamento e sua inserção na reprodução societária: historicamente, veículos da informação estiveram concentrados nas mãos da grande imprensa, de maneira que ainda hoje é possível observar, especialmente no Brasil, oligopólios (ou até mesmo monopólios) midiáticos. O desenvolvimento das Tecnologias da Informação e Comunicação foi premeditado por poucos conglomerados ao redor do mundo. De tal modo, foi possível a sucessiva expansão da configuração de seus monopólios. Segundo Chauí (2006, p. 59), a maior problemática em questão é a de compreender quais os gestores de "toda a massa de informações que controla a sociedade, quem utiliza essas informações, como e para que as utiliza”.

Ainda, hoje devemos atentarmo-nos às novas relações possibilitadas por intermédio das TICs. Os canais de informação tradicionais (como o rádio e a televisão) hoje não competem mais somente com o que criam, informam e disseminam, mas, também, com o que é criado e disseminado por indivíduos remotos em outros meios de comunicação, como os computadores pessoais e, mais recentemente, os smartphones.

Com a expansão do número de computadores domésticos, o rápido acesso ao ciberespaço por parte da população mundial facilitou a obtenção de informações preciosas pelos gestores dos meios de comunicação - mas isso nem sempre esteve claro. Wertheim (2001, p. 170), cede à uma breve epifania ciberentusiasta ao afirmar que:

O ciberespaço tornou-se, porém, muito mais que um mero espaço de dados, pois, como observamos, grande parte do que ali se passa não está voltado para a informação. Como muitos comentadores frisaram, o ciberespaço é usado fundamentalmente não para a coleta de informação, mas para a interação social e comunicação - e também, cada vez mais, para entretenimento interativo, o que inclui a criação de uma profusão de mundos de fantasia online em que as pessoas assumem elaborados alter egos. 
Diferentemente do que a autora expõe, sabemos que o poder de controle das massas hoje se dá, principalmente, pela centralização de dados obtidos nas redes, os quais são continuamente sistematizados e convertidos em novas fórmulas de condução de hábitos e interesses individuais. Como proclamou Clive Humby, um influente matemático e empreendedor londrino, “os dados são o novo petróleo”. Mas ainda é necessário pensar além: enquanto o petróleo consiste em um combustível fóssil finito, os dados se comportam como um "combustível" imaterial que se expande exponencialmente, conforme as pessoas utilizam a Internet e novos usuários se integram na rede.

Retomando a discussão sobre os computadores domésticos, segundo Chauí (2006), a chamada casa eletrônica ocasionou o desenvolvimento de um novo modo de vida pautado em dois atributos: a centralidade da casa e o individualismo. $\mathrm{O}$ primeiro refere-se ao alargamento do espaço privado e encolhimento do espaço público, reflexo de um novo plano econômico e de sociabilidade instaurado pela ideologia neoliberal. O indivíduo se vê possibilitado de efetuar atividades como se comunicar, comprar, fazer pagamentos e até mesmo trabalhar sem sair de sua própria casa. $\mathrm{O}$ segundo atributo simboliza a individualização, isto é, a organização do seu espaço e do seu tempo independente de seus familiares em casa. As antigas relações de sociabilidade sucumbem, muitas vezes, diante à ampliação das relações de sociabilidade digital. Como afirmou Santos (2012, p. 210) "o habitat dos homens era antigamente o seu lugar de residência e de trabalho e o espaço destinado às relações que uma vida social, geograficamente confinada, gerava através do processo produtivo, tanto nos seus aspectos materiais como nos seus aspectos não materiais”. Processo que denota não apenas a inscrição do ciberespaço aos circuitos de reprodução do capital, mas, também, na reprodução da materialidade espacial da reprodução social. Esgarçam-se relações que, reelaboradas, contraditoriamente, distanciam os sujeitos de sua condição coletiva e societária.

É sabido que as tecnologias da informação nunca se difundiram igualmente por todo o globo e, ainda, que grande parte da população mundial sequer possui acesso à Internet. Todavia, este fato não deve ser um impeditivo para compreensão da crescente influência dos computadores na sociedade contemporânea, e também o reconhecimento do colossal efeito dos smartphones na vida cotidiana da população.

\footnotetext{
${ }^{5}$ Frase original: “Data is the new oil”. Disponível em:

https://www.theguardian.com/technology/2013/aug/23/tech-giants-data. Acesso em: 29 mar. 2020.
} 
Segundo o levantamento do We Are Social, "Digital 2020 Global View Report”, o número de usuários de Internet (via desktop ou smartphone) em todo o globo atingiu 4,54 bilhões, o que representa um acréscimo de 7\% (298 milhões de novos usuários) comparados a janeiro de 2019. No Brasil, o levantamento revela que $71 \%$ da população possui acesso à Internet, independentemente da faixa etária. Deste modo, com o crescimento do número de usuários de Internet e, paralelamente, de smartphones, vivenciamos um novo paradigma social. A casa eletrônica tornou-se o prelúdio para uma nova etapa na humanidade: a do corpo eletrônico.

A primeira década do século XXI foi marcada pelo lançamento de inovações tecnológicas sob a premissa da facilitação, da praticidade e do status da mercadoria. Dentre os inúmeros produtos difundidos no mercado, os smartphones destacaram-se e foram popularizados com grande agilidade. Ainda mais rápida foi atualização dos aparelhos para versões cada vez mais sofisticadas, com o aumento do desempenho de processadores e da memória, telas touchscreen de alta resolução, baterias mais duradouras, câmeras aprimoradas e com o acesso à Internet por conexões sem fio ( $W i$ $\mathrm{Fi}, 3 G, 4 G$ e, em curso, o polêmico $5 G$ ), dentre outros inúmeros serviços possibilitados por softwares de variadas funcionalidades.

Diferentemente dos computadores, os smartphones não são aparelhos fixos. Ainda que as tecnologias tenham possibilitado a existência do notebook, seu uso ainda carece de locais específicos para sua conexão (como sua casa, seu trabalho ou cibercafés), além de outras características limitadoras de seu uso recorrente no dia-adia, como o tamanho e peso. Os smartphones se diferem por suas características de facilitação e praticidade: o tamanho (cabe em um bolso), mobilidade (pode ser transportado para qualquer lugar, sem pesar mais do que 200 gramas) e o acesso quase instantâneo. Hodiernamente, em virtude dos "telefones inteligentes", a conexão dos sujeitos ao ciberespaço não é mais dependente da locomoção a lugares específicos. Em outras palavras, houve a superação de limitações materiais do espaço por efeito dos avanços das Tecnologias da Informação e Comunicação. O acesso agora é semiinstantâneo, em qualquer tempo e em qualquer espaço. Os smartphones se fundem ao corpo humano como anexos ou "ciborgues", marchando da concepção de casa eletrônica para a do corpo eletrônico.

A máquina, agora, somos nós, algo que nos estrutura, um aspecto de nossa encarnação. Devemos ser responsáveis pelas máquinas: elas não nos dominam ou ameaçam. Somos responsáveis pelos limites: somos o mesmo que elas' e, portanto, elas são algo sujeito à construção e à desconstrução, um 
terreno onde passou a ser disputada nossa identidade, um campo onde, contraditoriamente, é certo, estamos tendo acesso a uma nova maneira de 'ver a ciência e a tecnologia e, potencialmente, a questionar a informática de dominação. (HARAWAY apud RÜDIGER, 2011, p. 120)

Ao afirmar que o corpo se funde gradualmente com as novas tecnologias, Lemos (2008, p. 165) discute como a formação do homem e a da técnica se dá por um processo simbiótico, isto é, "não se sabe ao certo se o homem produz ou é produzido por ela". Os ciborgues representam o motor para a cibercultura, ou seja, os agentes em simbiose carnal e maquinística que promovem a virtualização da cultura.

Nossa conversão em ciborgues e o desenrolar da cibercultura reconfigurou o modo como nos relacionamos com o mundo. Hoje, a cibercultura está expressa em nossos atos rotineiros mais banais, como em shows que costumamos frequentar e, ao invés de atentarmo-nos à apresentação, preocupamo-nos com o enquadramento dos músicos no vídeo que estamos gravando, a fim de compartilhar com pessoas remotas em nossas redes sociais. Ou, então, em nossas saídas com amigos que, mesmo na presença deles, desbloqueamos nossos celulares minuto-a-minuto para certificarmonos se não há algo mais interessante acontecendo. Tal como estudado por Debord (2000) em "Sociedade do espetáculo", nossa transformação em espectadores da realidade conduz à superestimação das representações imagéticas, ao passo que descentraliza a real notoriedade dos eventos. Além disso, tudo parece ocorrer no mesmo espaço e no mesmo tempo. Essa é uma possibilidade proporcionada pela técnica, que - não apenas hoje - modifica a experiência dos sujeitos com o mundo.

A maneira pela qual nos apropriamos do espaço está modificada pela cibercultura. Ora, é importante advertir que, enquanto nos vinculamos a um enredo previamente definido por quem controla o "tráfego" das redes e do ciberespaço tornamo-nos cada vez mais ciborgues: máquinas sem autonomia, controladas por outrem.

No tempo de micromáquinas, de redes digitais e da realidade virtual, todos nos transformamos em seres híbridos, cyborgs da civilização do virtual, onde a conexão a todo tipo de artefato torna-se, dia após dia, mais numerosa. A cibercultura contemporânea subverte esses dualismos a ponto de não sabermos direito onde começa o homem e onde termina a máquina. (LEMOS, 2008, p. 171)

Apesar da compreensão dos perigos da cibercultura, não devemos nos limitar à uma perspectiva unidimensional. A cibercultura apenas é possível pela existência do ciberespaço. O ciberespaço não é uma rede física, mas uma rede lógica, com sua própria linguagem. É neste ponto que devemos nos aprofundar: a construção da atual lógica 
do ciberespaço. Quando baseada em necessidades instrumentalizadas (ou protocoladas) por minorias dirigentes, a lógica se tornará cada vez menos solidária. Como afirmou Wertheim (2001, p. 221), “o ciberespaço é um caso paradigmático do poder de ‘fabricação do mundo’ da linguagem” e, ainda,

\begin{abstract}
Em cada nível da comunicação eletrônica no interior da Internet, há linguagens especiais, ou 'protocolos', que asseguram que todas as máquinas possam falar umas com as outras. O ciberespaço, como um mundo comunalmente partilhado, simplesmente não seria possível sem o poder imaterial da linguagem. Além dos vários 'protocolos da rede', há também protocolos especiais que determinam como textos, figuras, som e vídeo devem ser codificados para transmissão pela Internet.
\end{abstract}

Nota-se, portanto, que a problemática em questão não se resume ao ciberespaço, mas, em como ele é gerenciado. Quais são os protocolos estabelecidos na rede? E, talvez, o mais importante: quem os produzem? Sob quais premissas?

Ademais, outro fator importante e relativamente recente é o da atribuição do status de mercadoria aos smartphones, intrínseco à lógica do mercado e consumo.

Na sociedade da produção para reprodução ampliada do capital, os símbolos significantes de "status" contribuem para moldar a realidade espacial em curso. Como afirma Barbosa (2004), na sociedade contemporânea, a relação de dependência entre status e estilo de vida e de independência em relação à renda é rompida frente às novas relações de individualismo e de mercado. A passagem do consumo familiar para o consumo individual representa um processo em que identidades e estilos de vidas são previamente definidos, nos quais as escolhas individuais são condicionadas ou até mesmo subordinadas. Segundo Lemos (2008, p. 166), “a virtualização do mundo afeta de forma irreversível a sociedade contemporânea" e, ainda, "a partir da possibilidade de virtualização do mundo, tudo está disponível (possível) a uma requisição digital. $\mathrm{O}$ tudo é possível [...] mina o determinismo da racionalidade tecnológica que constitui o pilar da sociedade de consumo”.

Assim, entende-se que valorização da "carcaça eletrônica" das TICs mascara um amplo processo de (re)produção do espaço material por meio das imaterialidades possibilitadas pelos dispositivos tecnológicos. Sejam os setups fixos em domicílio ou smartphones posicionados em nossas mãos, o acesso ao ciberespaço se torna uma realidade veementemente banal e mecanizada por grande parte da sociedade contemporânea. A conversão ao desejo da mercadoria supera o questionamento de sua necessidade de obtenção. Nossa branda resistência em nos tornarmos os hospedeiros das tecnologias da informação e comunicação ao longo das décadas implicou (e ainda 
implica) drasticamente na reformulação de diversas dinâmicas, sejam elas políticas, econômicas, sociais ou culturais.

\section{VULNERABILIDADE SOCIAL NO ESPAÇO (I)MATERIAL}

O espaço imaterial do ciberespaço possui consequências objetivas sobre as práticas sociais contemporâneas. Ao passo que ele é um espaço construído, primeiramente, por entidades estatais e corporativas, também, é um espaço dinamizado por diversos agentes sociais remotos em suas relações cotidianas. O modo que estes sujeitos se apropriam do ciberespaço e o movimentam (com seus valores, suas morais e suas ideologias), certamente, deve se tornar um objeto de estudo. Assim, devemos compreender o ciberespaço enquanto um meio de difusão de signos e representações, um lugar onde ocorrem grande parte das experiências populares contemporâneas. Todavia, também precisamos nos atentar a quem são os produtores e reprodutores de tais signos e representações e, principalmente, como nos tornamos tão vulneráveis deles.

Conforme já dito, enquanto um produto instrumental de poder político e econômico, o ciberespaço proporciona mutações no espaço material. A transformação do comportamento individual - e ao mesmo tempo, coletivo - reconfigura as novas relações de sociabilidade inscritas no espaço geográfico. Novas configurações são observadas nos modos de se deslocar, alimentar, comprar, conversar, brincar, ler, se informar, fazer transações bancárias, entre outros costumes variados. Em princípio, estas ações surgiram do espaço material e, posteriormente, foram reconfiguradas pelas potencialidades do ciberespaço, que às (re)produzem continuamente.

Reconfigurar as práticas cotidianas dos seres sociais implica direta e indiretamente na reconstrução do espaço geográfico. O urbano (mas não somente ele) e suas relações são (re)produzidos à medida que novas dinâmicas são confeccionadas pela lógica do capital. A título de exemplo, o deslocamento hoje é possibilitado tanto pelo transporte público, quanto pelo privado. Mais recentemente, uma nova modalidade de transporte privado emergiu na sociedade (e nas ruas) de maneira avassaladora, os chamados Ubers, ou também, motoristas de aplicativo. Além das novas dinâmicas de deslocamento, a alimentação passou a ser muitas vezes intermediada por aplicativos específicos para tal segmento, como o iFood e o - não coincidentemente - UberEats. Nestes, é possível selecionar a comida desejada, no 
estabelecimento desejado, com a forma de pagamento desejada e o endereço de entrega em apenas alguns cliques, sem a necessidade de se locomover até ao restaurante, pois o alimento vai até você (numa visão alienada que tende a ocultar todo o processo produtivo e, principalmente, a figura e importância do trabalhador).

Com o universo das compras também não seria diferente: a nova modalidade de comércio intitulada e-commerce (abreviação de electronic commerce) se expande sem qualquer revés, esvaziando as lojas físicas nos centros das cidades e abarrotando galpões de estoques na margem das rodovias. Como afirmou Santos (2012, p. 205), "as novas atividades exigem um lugar no espaço e impõem uma nova arrumação para as coisas, uma disposição diferente para os objetos geográficos, uma organização do espaço diferente daquela que antes existia”. Ainda, Santos (2017, p. 239) afirma que "os espaços requalificados atendem sobretudo aos interesses de atores hegemônicos da economia, da cultura e da política e são incorporados plenamente às novas correntes mundiais". Desta maneira, o meio técnico-científico-informacional enquadra-se como uma expressão aparente da globalização sobre o espaço geográfico. Em contraponto, há que as necessidades (reduzidas a serviços) são supostamente atendidas sem a clara interação social, obscurecida por mecanismos tecnológicos que transforma o mundo em um catálogo de compras para o atendimento de necessidades de consumo cuja produção é, cada vez mais, artificial e externamente definida.

Ao nos alcançar nesses termos, alterando e moldando nossos hábitos, esse processo também altera o fazer/saber coletivo, (re)produzindo a cultura que deles resulta, na forma de uma cibercultura. Segundo Rüdiger (2011, p. 183), a cibercultura é caracterizada pelo "conjunto de práticas e representações que surge e se desenvolve com a crescente mediação da vida cotidiana pelas tecnologias de informação". As tecnologias da informação prosperam em função dos sentidos (direcionais e sentimentais) engendrados nos "movimentos libertários e dos agenciamentos políticoeconômico promovidos pelos Estados e corporações". Em vista disso, "somos postos em redes e incentivados a operar seus terminais como sujeitos sistêmicos de uma era dominada pela razão instrumental e o fetichismo da mercadoria tecnológica virtual maquinística”. Ainda, Santos (2017, p. 187) nos ensina:

A cidade moderna nos move como se fôssemos máquinas, e os nossos menores gestos são comandados por um relógio onipresente. Nossos minutos são os minutos do outro e a articulação dos movimentos e gestos é um dado banal da vida coletiva. Quanto mais artificial é o meio, maior a exigência dessa racionalidade instrumental que, por sua vez, exige mais artificialidade e racionalidade. 
Nos termos em que se desenvolveu, a produção de um espaço é também a produção dos indivíduos que o habitam. Produzir indivíduos condizentes aos ideais predeterminados permite a produção, destruição e reprodução do espaço e das coisas, inscrevendo os sujeitos num turbilhão incessante, porém fundamental, para a reprodução ampliada e circulação do capital. De tal modo, a alienação condicionada dos seres os torna submissos e reprodutores daquilo que os ensinam como sendo legítimo.

Quando Paulo Freire (1987) nos ensina que a educação não transforma o mundo, mas muda pessoas e são estas quem transformam o mundo, o mesmo aplicase para as técnicas. As técnicas não reconfigurariam o mundo sem seres que as dessem sentido. O "sentido" aqui empregado é polissêmico: representa tanto a esfera da sensibilidade, quanto o direcionamento. É isso o que chamo de vulnerabilidade social no espaço (i)material. O social torna-se cada vez mais vulnerável, tanto no espaço material, quanto no imaterial, porque nas técnicas se convergem diferentes sentidos, que nos direcionam e nos fazem sentir as contradições desta relação dualista. Como afirmou Randolph (2005, p. 134), “apesar de estarem relacionadas ao espaço vivido, as manipulações [técnicas] devem ser compreendidas como práticas espaciais, na medida em que transcendem a mera esfera das representações imateriais (simbólicas)”.

Deste modo, ao discorrer sobre as práticas sociais comuns existentes em um espaço específico, também estamos discutindo sobre representações culturais. Aplicase, dessa maneira, o espaço imaterial também como um "ambiente" da promoção de valores, prazeres, pretensões e utopias, que partem inicialmente de um espaço material. Assim, o espaço imaterial (o ciberespaço) desencadeia a noção da “cibercultura”, difundida por Pierre Lévy.

A conversão da cibercultura em novo parque de diversões, gerenciado pelos próprios usuários, por isso, pode se apenas a face risonha e vulgar de um processo mais abrangente que, operando em todas as instâncias de nossa civilização, trabalha no sentido de, por um lado, reduzir o homem a um mecanismo de reações automatizadas, e, por outro, a convertê-lo, plural, mas desigualmente, em sujeito sistêmico de uma ordem social e tecnológica prospectivamente maquinística. (RÜDIGER, 2011, p. 281)

Em continuidade ao raciocínio, Randolph (2005, p. 139) afirma:

Nesse novo espaço de simulação (ficcional), surgem novas formas de subjetivação (socialização) e de formação de identidades (personalidade) através de um processo de desconexão (virtualização, afastamento e 
distanciamento) que, pela qualidade da simulação, será complementado por uma reconexão através de 'atualizações virtuais', 'presenças imateriais' e o pertencimento mediato que as tecnologias tradicionais (não-interativas) não permitiam em grau suficiente [...]

Sob a perspectiva de Chauí (2006), compreendemos a atual condição das pessoas a um simulacro da realidade, no qual elas creem determinar o ritmo e tomar suas próprias decisões quando, na verdade, pela leitura e interpretação de suas emoções e comportamentos, são induzidas a quererem, fazerem ou se comportarem tal como demanda o mundo descartável da obsolescência programada. Segundo Harvey (2017, livro digital) "a obsolescência programada, a inovação, o modismo e coisas assim estão profundamente enraizados na cultura capitalista”. Dessa maneira, quase tudo é superficial, descartável e sujeito a ser substituído pela "inovação" imposta por um sistema que não nos demanda na nossa condição humana, mas na de autômatos que consumirão o que a eles for direcionado, por meio de um trabalho que nos escraviza e nos deforma, pois nos impede de desenvolver nossa real virtualidade, reduzindo-nos a apenas ao que o "mercado" demanda de nós. No jogo instrumental e maquiavélico da cibercultura capitalista, pessoas são cada vez mais desumanizadas, ao passo que, máquinas tornam-se cada vez mais antropomorfizadas.

É nessa perspectiva que se entende a inegável interrelação socioespacial anexada aos processos do ciberespaço enquanto produto e (re)produtor do espaço geográfico. O social desenvolvido no espaço material é, desta forma, transformado continuamente pelo ciberespaço. As relações sociais são muitas vezes estabelecidas pela instrumentalização de poderes a partir de determinados interesses e ocasiões nele arquitetadas. A modulação deste espaço imaterial é, por conseguinte, promovida pela submersão individual dos sujeitos exploradores, que demandam a produção de novos espaços suportados pelo mecanismo da Internet (e o espaço criado por ela), para o desenvolvimento de novas relações de significância e confortabilidade.

Conquanto Lévy (1999) ressalte a importância de não se confundir a realidade virtual com a realidade cotidiana, as dimensões da influência do virtual sobre o cotidiano no mundo contemporâneo não podem ser negadas.

É impossível separar o humano de seu ambiente material, assim como dos signos e das imagens por meio dos quais ele atribui sentido à vida $\mathrm{e}$ ao mundo. Da mesma forma, não podemos separar o mundo material - e menos ainda sua parte artificial - das ideias por meio das quais os objetos técnicos são concebidos e utilizados, nem dos humanos que os inventam, produzem e utilizam. (LÉVY, 1999, p. 22) 
De acordo com Santos (2017), as novas tecnologias "envolvem muito mais pessoas e colonizam muito mais áreas do que as técnicas anteriores”. O rádio, procedido pela televisão e pelo computador de uso doméstico, "invadiram" cada vez mais os domicílios. Hoje, os smartphones e smartwatches invadem não somente nossas casas, mas nossos corpos. A relação quase parasitária das novas tecnologias abstrai informações e subtrai os espíritos em sua tentativa de homogeneização global. Somos reduzidos a meros algoritmos, explorados por nossas vulnerabilidades e induzidos ao consumo desejado pelo mercado. Em outras palavras, retiram do indivíduo as informações necessárias para (re)produzir o sujeito que o capital necessita que seja produzido. O que está em curso é uma significativa inversão produtiva. Possivelmente somos testemunhas factuais de uma época em que não se produz mais o produto para o indivíduo, mas este para o que foi produzido.

Como afirmou Randolph (2005, p. 138), "a questão da relação entre o 'real' (racional) e o 'imaginário' (fictício) está presente em qualquer manifestação cotidiana em sociedades onde o consumo está organizado ou intermediado pelas mídias”. Ainda, segundo Lévy (1999, p. 24), "por trás das técnicas agem e reagem ideias, projetos sociais, utopias, interesses econômicos, estratégias de poder, toda a gama de jogos dos homens em sociedade". Assim são funcionalizados o ciberespaço e as tecnologias: como peças valiosas postas sobre um tabuleiro neoliberal cada vez mais hostil e competitivo.

Retornando à discussão dos meios informacionais, o termo mass media (mídia de massa, em português) apresentado na obra de Lasch (1983) e apropriado por Chauí (2006, p. 8) confere ao fato de que as informações disseminadas em veículos multimídia "tornaram irrelevantes as categorias da verdade e da falsidade substituindo-as pelas noções de credibilidade ou plausabilidade e confiabilidade - para que algo seja aceito como real basta que apareça como crível ou plausível, ou como oferecido por alguém confiável”. Assim, não são mais propriamente informações, mas "preferências que se convertem imediatamente em propaganda". Tais afirmações se tornam muito evidentes ao estudarmos, por exemplo, o período eleitoral brasileiro de 2018, quando a batalha dicotômica entre a direita e a esquerda do país saturou os dispositivos eletrônicos de grande parte da população, com as famigeradas fake news.

Fortalecida pela desinformação, fenômeno potencializado pelas mídias digitais, a extrema-direita brasileira garantiu o engajamento necessário para alcançar o cargo da presidência da República, assim como demais postos de grande influência 
política em todo o país. Segundo Fernandes (2019, livro digital), as fake news não foram o único fator influenciador neste processo, mas ainda assim foram demasiadamente influentes. Ao considerar que na era da pós-verdade "as mentiras passam a ser levadas a sério, não por mera desinformação, mas porque compactuam com a versão da realidade reafirmada pelos afetos centrais do senso comum", devemos compreender que a construção, organização e controle deste mesmo senso são dadas por agentes hegemônicos, que se apropriam de diferentes instrumentos informativos e comunicativos (como o ciberespaço) para fins lucrativos ou de vigilância. Diante disso, a autora discute que observamos a "inauguração de uma nova era em que significados e significantes não mais se encontram em combinações politizadas e dotadas de credibilidade, mas da suspensão radical do encaixe entre significados e significantes".

Dentre variados exemplos, tomemos o aplicativo de mensagens instantâneas Whatsapp como objeto para breve análise. Este consiste num meio pessoal e supostamente secreto (protegido pelo sistema de criptografia) para a comunicação entre usuários em diferentes localidades. Seu uso pode variar do envio de mensagens de texto ou voz para familiares, ao compartilhamento de vídeos engraçados com amigos, até ao envio de documentos formais ao seu supervisor. O uso do aplicativo permite a rápida e superficial comunicação cotidiana através de um eletrônico que se estabelece como anexo do corpo humano. Ao vibrar de volta, é possível saber instantaneamente onde está seu irmão, qual foi a reação de seu colega ao vídeo ou se o documento enviado necessita retificações. De acordo com Fernandes (2019, livro digital), assim "se estabelece em um novo habitat comunicativo, formado pela Internet, um habitat de algoritmos e afetos. Isso se reflete nos locutores e interlocutores e nos milhões de mensagem multiplicadas, não somente em conteúdo, mas também nas cargas afetivas de cada comunicação".

Certamente, nem todo ato de comunicação traz informações proveitosas, em vista que, a noção de credibilidade ou plausabilidade muitas vezes se desconfiguram no mundo cibernético. Toda informação é tendenciosa, no bom ou mau sentido. Ainda que muitas vezes a mass media (Chauí, 2006) se diga neutra, podemos observar posicionamentos pelo simples ato de neutralidade frente a variadas questões. No entanto, embora ocultas, suas intencionalidades ainda visam concorrer pela credibilidade na informação com outras imprensas. Caso as informações de uma sejam absurdamente falsas, sua marca poderá cair em descrédito. Por outro lado, canais de 
informação como o Whatsapp não se inserem em tal lógica de veracidade, visto que, não representam uma fonte de informação "legítima", mas apenas um veículo de transmissão de mensagens "afetuosas" (entre familiares, amigos e semelhantes). Assim, muitas de suas ilegitimidades são naturalizadas por grandes parcelas da população, que às disseminam.

[...] a dimensão da comunicação e da informação, então está se transformando numa esfera informatizada. O interesse é pensar qual o significado cultural disso. Com o espaço cibernético, temos uma ferramenta de comunicação muito diferente da mídia clássica, porque é nesse espaço que todas as mensagens se tornam interativas, ganham uma plasticidade e têm uma possibilidade de metamorfose imediata. E aí, a partir do momento em que se tem o acesso a isso, cada pessoa pode se tornar uma emissora, o que obviamente não é o caso de uma mídia como a imprensa ou a televisão. (LÉVY, 1994, p. 1)

As redes virtuais contribuem para uma profunda modificação das formas de percepção e compreensão. De acordo com Randolph (2005, p. 136), a adoção de novas ferramentas pelos homens não significou, historicamente, em qualquer circunstância, o surgimento de novas práticas sociais, mas sim a rearticulação em termos da percepção e concepção nelas obtidas. O autor, em certos momentos, aponta a limitação de Castells ao tratar das redes como um universo de auto-regulação, isto é, independentes de agentes em sua fluidez. Tomando a perspectiva de uma categoria sociotécnica, Santos (2017, p. 275) discute:

Ela [a fluidez sociotécnica] não alcançaria as consequências atuais se, ao lado das inovações técnicas, não estivessem operando novas normas de ação, a começar, paradoxalmente, pela chamada desregulação. A economia contemporânea não funciona sem um sistema de normas, adequadas aos novos sistemas de objetos e aos novos sistemas de ações, e destinadas a provêlos de um funcionamento mais preciso [...]. Ao contrário do imaginário que a acompanha, a desregulação não suprime as normas. Na verdade, desregular significa multiplicar o número de normas.

O pensamento de Castells, de acordo com Rüdiger (2011, p. 142), pressupõe que "as redes criam e se recriariam de acordo com programas que se originam sistemicamente delas mesmas" e, ainda, "os seus atores eventualmente dispõem de poder de interferir e, eventualmente, reprogramá-las, graças aos recursos que estas redes mesmas disponibilizam". Dessa maneira, o autor esvazia ou simplesmente ignora a atuação de agentes sociais e supra-sociais, como os políticos, econômicos e até militares na construção das tecnologias, reafirmando uma postura tecnocrática de auto-regulação. Torna-se importante salientar que não há uma relação de 
determinância de ordens sobre outras, mas de condicionamentos de diversas instâncias em uma dinâmica sistêmica, como afirma Rüdiger (2011, p. 138)

Evidentemente que, em tudo isso, reside aí um problema, porque, [...] a lógica que comanda a rede (canalização, aceleração, barateamento e expansão da informação) e engendra a cibercultura não é apenas tecnológica, precisa ser vista, como [...] parte de blocos históricos em que intervêm interesses e ideias de várias outras ordens.

A noção de coletividade proporcionada pelas novas tecnologias mobiliza as relações sociais existentes e potencializa a expansão dos grupos em rede. As alegorias tecnológicas e a interatividade gerada a partir destas ainda são "agenciadas socialmente por empresas e instituições”, como afirma Rüdiger (2011, p. 278), o que promove a "troca de nossa submissão voluntária ou involuntária às suas formas de colher informações de maneira cada vez mais detalhada e passível de exploração" (ANDREJEVIC apud RÜDIGER, 2011, p. 278).

É importante salientar que os agentes sociais não devem ser os únicos (nem os maiores) responsabilizados pela construção das redes. A ausência de ideias associadas à integridade de diversos atores em conjuntura na formação das redes no decorrer da História recai sobre um reducionismo - perigoso - da realidade. Como discutiu Harvey (2017, livro digital), “as mudanças tecnológicas do capitalismo, para as quais contribui e das quais se alimenta com voracidade, derivam, em suma, da atividade de vários agentes e instituições”. Como também afirmou Santos (2017, p. 104), “uma técnica nunca aparece só e jamais funciona isoladamente”.

Vista crítica e historicamente, a cibercultura é, com efeito, um processo de exploração da informática de comunicação pela sociedade capitalista que, se, por um lado, assume e reproduz mercantilmente as funções originárias da técnica da experiência de sobrevivência da humanidade ocidental, por outro se conecta com um projeto que, avaliado em sua perspectiva, transcende a explicação histórica ou sociológica. O fenômeno materializa socialmente a velha inclinação humana a deixar de lado o princípio da realidade e a mergulhar nos prazeres do imaginário, embora nem por isso deixe de carregar consigo os prejuízos e patologias que, antes de pura e simplesmente provirem do real, nascem da nossa incapacidade de elaborar crítica e regular moralmente nossos desejos e imaginação criadora nas sucessivas épocas da história. (RÜDIGER, 2011, p. 280)

Ao surgir na sociedade - ou no mercado - as novas técnicas não dão fim às antigas. É preciso considerá-las como coexistentes no espaço. Toda inovação é contrastada perante aos objetos já obsoletos. Tal contradição, de certa maneira, tornou-se também um instrumento de potencialização da mercantilização do novo. 
Nessa racionalidade, considera-se o inovador como necessário e o ultrapassado como descartável.

Em muitos aspectos, a arquitetura do ciberespaço passa a superar a arquitetura material quando atrelada à sensibilidade subjetiva dos seres. Neste ponto, as relações de significância e confortabilidade construídas no espaço imaterial por sujeitos individuais podem desconstruir antigos padrões de sensibilidade e comportamentais, criando novas intervenções no imaterial e, consequentemente, no material. Desta maneira, o ciberespaço atua como fragmentador do tecido do espaço material e dos sujeitos que o habitam. Contudo, o estágio da fragmentação é consequencial, efeito de dois momentos que o antecedem: a individualização e a despersonalização.

\section{A individualização}

Como já discutido, o ciberespaço não foi uma criação do mercado para si, mas um produto do desenvolvimento técnico da ciência (re)apropriado para o mercado. $\mathrm{O}$ capital não se reproduz a partir da inovação (uma força motriz do homem), mas da apropriação de tudo e de todos (inclusive do homem e sua criatividade) no seu circuito de reprodução. A sociedade, enquanto instituição coletiva, foi primordialmente fundamental para a evolução técnica e cultural do mundo no decorrer dos milênios. Entretanto, esta viu seus esforços sendo gradativamente canalizados numa lógica ostensiva de expansão capitalista desde o século XVI, que à tem reduzido muitas vezes, como temos observado, em seu menor átomo: o indivíduo.

A apropriação dos homens em sociedade foi um pilar crucial para a consolidação do capitalismo, desde seu período mais primitivo. A partir dessa relação, estabeleceu-se a forma hierárquica dos mais ou menos privilegiados socialmente, ou melhor dizendo, a chamada sociedade de classes, como discutido por Marx e Engels (1975). A exploração massiva da mais-valia, em sua práxis, estruturou o mundo capitalista tal como o conhecemos: fundado sobre desigualdades e contradições. $\mathrm{O}$ desdobramento de séculos baseados na busca predatória pelo lucro e na miséria instituída, deste modo, segregou classes, que desenvolveram seus próprios mecanismos de resistência contra a dominância de seletos grupos de poder.

O fator da identificação, fortemente atrelado à uma sociedade coletiva e humanitária, promoveu um caráter imunitário vital diante ao "vírus" do segregacionismo capitalista. A partir dele, lutas sociais foram (e ainda são, de certo 
modo) travadas pelo mundo como formas de oposição à subordinação de mulheres, pretos, indígenas, homossexuais, judeus, ciganos e múltiplos outros grupos subalternos. Todavia, a identificação que antes figurava o elemento primordial para conjunção de grupos minoritários, hoje, encontra-se vulnerabilizada pelos efeitos da individualização, produto de um reconfigurado modelo capitalista: o neoliberalismo. Isso não significa que as identidades foram apagadas, mas sim re-apropriadas na forma de mercadorias vazias de significado e destituídas de força política contra-hegemônica. Este é o chamado identitarismo liberal, que atua como a maquiagem para nossa vulnerabilidade, tanto no espaço material, quanto no imaterial.

A eficiência da armadilha identitária está no seu duplo funcionamento, que serve tanto à "direita” quanto à "esquerda antirrevolucionária”. Em relação à direita, o uso da política identitária e da insistência subjetivista é algo tradicional e faz parte do individualismo mercadológico que é a marca do liberalismo e do neoliberalismo. (HAIDER, 2019, livro digital)

A individualização dos seres é inserida socialmente enquanto mecanismo de defesa e reprodução ampliada do próprio capital. Primeiro, porque fragiliza a relação identitária entre grupos e lutas de classe, na medida que, o indivíduo não se reconhece mais na identidade de seu semelhante e na vulnerabilidade do outro. E, segundo, porque se torna mais rentável a cisão da coletividade consumidora, uma vez que, cada indivíduo consumindo por si amplia o escopo de consumidores potenciais. É neste sentido que a instituição familiar foi fragmentada dentro de seu próprio lar.

Tomemos como ponto de análise um conceito já abordado neste trabalho: a casa eletrônica é uma clara representação do processo que acabo de apontar. A individualização, em sua essência, está expressa pelos nossos atos mais banais e incrustados em nossas mentes. Por que, ao longo das últimas décadas, atribuímos como necessidade a existência de aparelhos televisores em quartos individuais, sendo que, uma televisão pode ser assistida por todos na sala? Por qual motivo cada membro de uma família (quando financeiramente possível) precisa de um carro próprio, sendo que, um carro, em regra, possui cinco assentos? Estas são questões que, embora não sejam respondidas aqui, apontam para a relevância da reflexão desenvolvida a seguir.

Além da casa eletrônica, deparamo-nos com a concepção de corpo eletrônico, ao analisarmos nosso elo com dispositivos pessoais (como computadores e smartphones). Também nesse ponto emerge o ciberespaço. A conexão possibilitada pela Rede Mundial de Computadores (hoje também composta por dispositivos móveis), a Internet, e os indivíduos em sua complexidade envolvida (desde os que 
gerenciam aos que apenas utilizam) moldam as relações existentes no ciberespaço e, consequentemente, no mundo material. Uma vez imerso em um mundo virtual (não à parte!), o sujeito não será mais o mesmo, reproduzindo seu "novo eu" na materialidade, assim que "se desconectar" deste espaço imaterial. O novo eu, este, nada mais é do que a transformação de um eu preexistente, que foi (re)produzido no espaço imaterial, isto é, um sujeito (re)produzido pelo ciberespaço.

A título de exemplo, lembremos quando Marx (1971) explicou o capital por sua fórmula geral: D-M-D'. O dinheiro (D), que consiste numa forma de representação do valor, quando convertido em mercadoria (M) e valorizado, resulta no dinheiro inicial somado ao lucro obtido (D') a partir da captura da mais-valia gerada pelo trabalho inserido (e explorado) no processo de produção. A mesma estrutura de fórmula pode ser aplicada à lógica do ciberespaço. O espaço material ( $M$, que envolve tudo e todos), quando inserido no espaço imaterial do ciberespaço ( $I$ ), é "valorizado", ou melhor dizendo, (re)produzido para criação de um sujeito que será posteriormente "lucrado" $\left(M^{\prime}\right)$ de acordo com as intencionalidades de quem produziu o mundo virtual (do mesmo modo que quem produziu a mercadoria). Resumidamente, o sujeito inserido no ciberespaço "retorna à materialidade" com certo "valor agregado". Esse valor representa o sujeito (re)produzido para a manutenção da racionalidade que o produziu, numa dinâmica M-I-M’6. Assim, sucessivamente, o espaço geográfico é (re)produzido pela manutenção dos sujeitos e objetos inseridos no ciberespaço.

É na constante dinâmica da (re)produção dos sujeitos, sob os ideais neoliberais contemporâneos, que o ciberespaço é apropriado tal como uma mercadoria por todos os indivíduos. Todavia, enquanto essa mercadoria é consumida de forma aparentemente gratuita por seus usuários, estes últimos são consumidos e pagam pelo seu uso através um outro tipo de moeda: seus próprios dados.

O indivíduo se reduz a um fluxo de dados que pode ser reorganizado e vendido de acordo com os interesses de potenciais anunciantes, os quais, de posse dessas amostras compradas, invadirão os acessos dos indivíduos ao ciberespaço com propagandas já direcionadas para seus gostos. (CHAUÍ, 2017, p. 32)

Consequentemente, somos cada vez mais conhecidos por aqueles que desejam nos (re)produzir, que nos direcionam à uma individualidade generalizada, nos

\footnotetext{
${ }^{6}$ Fórmula sistêmica da produção e (re)produção do espaço geográfico: Material-Imaterial-Material'. Analogia à fórmula sistêmica do capital D-M-D' estudada por Karl Marx no Volume I de "O Capital”.
} 
tornando vulneráveis, artificializados e cada vez mais despersonalizados de nossos "eus".

\section{A despersonalização}

Numa época de colapso social e familiar generalizado no mundo ocidental, um número crescente de pessoas sofre de isolamento, solidão e alienação [...] A Internet, com sua vasta teia global, acena para todos nós com uma visão de amizade e a esperança de inclusão num todo social mais amplo. (WERTHEIM, 2001, p. 207)

Como afirmado anteriormente, o consumo de tecnologias da informação e comunicação se tornou um símbolo de pós-modernidade e status. Quando mencionamos a existência de um tipo de espaço imaterial como o ciberespaço, automaticamente nos referimos a um lugar onde nossas formas de representação passam a ser apostadas num cenário idealístico, presunçosamente "sem leis". Segundo Wertheim (2001, p. 207), “a promessa de uma comunidade utópica é na verdade um dos atrativos do ciberespaço”. Em outras palavras, um mundo que supostamente figuraria um local sem que necessitássemos expor nossas aparências e reinaria a essência, na realidade, é mera utopia. Sendo o espaço geográfico o conjunto de suas materialidades e imaterialidades, este está subordinado a suas formas de representação aparentes, sob as quais devemos nos dispor a desvendar as essências existentes por trás dos fenômenos e processos.

É nesse sentido, então, que as redes globais de computação podem ter a capacidade - como a tiveram todas as inovações tecnológicas voltadas para a circulação do conhecimento - de contribuir para o 'surgimento' de novos espaços de representação, os quais significariam o 'mero prolongamento' de uma trajetória há muito em curso nas diferentes partes do mundo. (RANDOLPH, 2005, p. 134)

O bombardeamento de imagens e formas de representação, possibilitado pelos os avanços tecnológicos, tem afetado nossas percepções de mundo e modo com ele nos relacionamos. O mundo atual é dominado por nuvens informacionais. Tal nebulosidade demonstra, segundo Wisnik (2012), o estado contemporâneo atual: um período de incertezas e de um grande nevoeiro que circunda e nos impossibilita de enxergar a realidade tal como ela é. Isto ocorre em função de nevoeiros trazidos por sociedades de massa que impõem verdades supostamente aparentes, absolutas, ditas e explicadas e, culminam no silêncio da conformidade. Processo que, no limite, mina nossa subjetividade, porque reduz ou atrofia nossa capacidade de identificar nossos reais anseios e desejos que são, cada vez mais, artificialmente produzidos. 
Ainda, de acordo com Wisnik (2012), mesmo que vivamos em um período de domínio do nevoeiro, devemos compreender este período também como um domínio da nitidez. Somos direcionados à uma nitidez de representações impostas, que visam mascarar ou até mesmo suprimir a verdadeira essência dos sujeitos e dos objetos. Como abordado por Chauí (2006), o que se figura é um simulacro, isto é, uma forma deturpada de se conceber a noção dos fatos tais como eles são. Assim, a despersonalização, precedida pela individualização, constrói seres cada vez mais artificiais em seus próprios espaços de vivência. A criação de uma sociedade despersonalizada nos debilita de nossas identidades próprias e sociais, o que nos conduz à uma tentativa de homogeneização global: a nivelação de rugosidades $^{7}$ que normalmente tendem a refrear a expansão acelerada do capital.

O que se sucede é o xeque-mate dos efeitos do ciberespaço sobre o espaço geográfico. A fragmentação dos sujeitos e dos lugares se torna possível, na medida que, uma sociedade despersonalizada se torna gradativamente desarticulada, despolitizada, inconsciente da realidade e, consequentemente, subordinada e impotente diante das hegemonias contemporâneas que à controla.

\section{A fragmentação}

[...] as práticas reticulares determinam lentamente o surgimento de um novo tipo de subjetividade que não se define mais pelas relações do corpo com o espaço e o tempo do mundo ou da vida, mas com a complexidade de relações artificiais que permanecem esparsas e fragmentadas. (CHAUÍ, 2017, p. 31)

A despersonalização, caracterizada pelo ato de reconfigurar profundamente a subjetividade dos indivíduos, desdobra-se, consequentemente, no ato da fragmentação dos sujeitos e do espaço habitado por eles. Modificar práticas culturais significa, também, transformar o espaço e as dinâmicas geográficas.

"A mistura de tempos na mídia dentro do mesmo canal de comunicação, à escolha do espectador/integrante, cria uma colagem temporal em que não apenas se misturam gêneros, mas seus tempos tornam-se síncronos em um horizonte aberto sem começo, nem fim, nem sequência. A intemporalidade do hipertexto de multimídia é uma característica decisiva de nossa cultura, modelando as mentes e memórias das crianças educadas no novo contexto cultural”. (CASTELLS, 1999, p. 553)

Ainda, a fragmentação e a dispersão espacial desdobram-se numa suposta “aproximação” possibilitada pelas TICs que, na verdade, (re)produz sujeitos cada vez

\footnotetext{
${ }^{7}$ Conceito de Milton Santos, desenvolvido em sua obra "A natureza do espaço: Técnica e tempo. Razão e emoção" (2017).
} 
mais vulneráveis e fragmentados nesse processo. Vivenciamos uma mecanização da expressão humana, que se dilui nos conceitos de atopia e acronia, como apontado por Chauí (2006).

Ao discutir sobre os ciborgues contemporâneos, mencionei que tudo parece ocorrer no mesmo espaço e no mesmo tempo. A atopia é o conceito que representa a ausência referencial de espaços próprios do corpo humano e da percepção. Neste processo, todos os fatos parecem ocorrer em um único lugar, ao mesmo tempo e que também parecem ocorrer em lugar nenhum. Já, a acronia representa o déficit de um referencial temporal, isto é, todos os fatos parecem acontecer ao mesmo tempo e também em tempo algum. Contudo, não devemos considerar que tal produção de subjetividade está desligada do espaço e do tempo, por mais fabulosa que ela seja, como Chauí (2017) indica - mas que parte das próprias contradições do espaço geográfico. O mundo virtual, como sabemos, não se caracteriza como um plano inexistente, dado que, não se desprende de uma dinâmica espaço-temporal, e sim surge dela e potencializa suas (re)produções. O virtual são possibilidades, transformadas em instrumentos intencionais para atualizar a Geografia mundial.

Embora exista uma complexa multiplicidade de resultantes da cibercultura no espaço geográfico, enfocarei na tríade do isolamento individual, encolhimento do espaço público e alargamento do espaço privado ${ }^{8}$.

O isolamento individual é o processo chave para que compreendamos os demais. Sob a potencialidade de individualização e despersonalização promovidas pelo ciberespaço, o primeiro ato de fragmentação ocorre no que se figura o isolamento individual. Esse processo não significa que o sujeito passa a se isolar de todo o espaço material que o circunda, mas num "rompimento" psicossocial de desidentificação com muitos aspectos do mundo material, como os movimentos políticos. Ainda que o ciberespaço permita a conexão de pessoas com desejos e ideais semelhantes em rede, estes sentimentos são, concomitantemente, bombardeados por atores externos que retroalimentam a desarticulação e distanciamento do que, porventura, seria uma luta política e resistente. Aqui são minadas as possibilidades de emancipação social. Por que no atual Brasil, mesmo com milhões de pessoas conectadas em redes sociais, costumamos observar minúsculas movimentações de cidadãos nas ruas, em paralisações e protestos, organizados por sindicatos trabalhistas ou movimentos

\footnotetext{
${ }^{8}$ Conceitos trabalhados por Marilena Chauí em sua obra "Simulacro e poder: Uma análise da mídia" (2006).
} 
estudantis? Desnecessário demonstrar que trabalhadores e estudantes não são classes quantitativamente pequenas no país...

O encolhimento do espaço público e o alargamento do espaço privado estampam a materialização do fenômeno psicossocial do isolamento individual. Encolher um espaço público implica, diretamente, na supressão das expressões populares, que são dispersas de suas funções de participação política, social e cultural. A não-apropriação de espaços materiais públicos (como as universidades) e a submissão em espaços imateriais (desde o ciberespaço ao direito de fala) por essas parcelas implica, inevitavelmente, na privatização do espaço (e, consequentemente, dos seres que o habitam). Consolida-se, deste modo, um dos pilares de maior importância para a ideologia neoliberal.

E, sem dúvida, o encolhimento do espaço público e o alargamento do espaço privado colocam em evidência o bloqueio a um direito democrático fundamental, sem o qual a cidadania, entendida como participação social, política e cultural é impossível, qual seja, o direito à informação. (CHAUÍ, 2017, p. 21-22)

Segundo Ramires (2017, p. 40), "o ciberespaço, enquanto produto, condicionante e reflexo da sociedade, comporta conflitos e contradições da contemporaneidade”. À sua maneira, ou melhor dizendo, à maneira daqueles que o controlam, ele se torna também um (re)produtor social e do espaço geográfico, composto por conflitos e contradições que variadas vezes se estruturam em novos tipos de barreiras socioespaciais. Como afirmou Raffestin (1993), as redes (como o ciberespaço) fazem e desfazem as prisões do espaço material (o território). Tanto libertam como aprisionam, atuando como instrumento, por excelência, do poder.

Tanto os agentes hegemônicos que produzem, quanto os agentes sociais que são influenciados e direcionados para a manutenção desse sistema estritamente ampliador do capital, o reproduzem. Mesmo que todos sejam influídos nesta lógica, é evidente que, aqueles que controlam o sistema denotam o topo da pirâmide hierárquica mundial. Mas, embora figurem o topo, esta não é uma pirâmide sólida o bastante, uma vez que, sempre é intemperizada pelas contradições internas e externas do próprio capital.

A hierarquia social se tornará mais vulnerável, na medida que, a base se movimentar radicalmente, tal como as raízes de uma árvore que promovem o intemperismo físico do solo (a estrutura que o nutre) ao crescerem e buscarem por outros nutrientes. A revolução deve, sempre, vir da base. Tal como afirmou Santos 
(2000, p. 170), "esse mundo novo anunciado não será uma construção de cima para baixo, como a que estamos hoje assistindo e deplorando, mas uma edificação cuja trajetória vai se dar de baixo para cima”. Para isso, torna-se primeiramente necessário compreender as prisões em que nos encontramos, para depois nos libertamos delas. Deste modo, devemos compreender o ciberespaço, tal como suas armadilhas, para que não nos tornemos indivíduos cada vez mais despersonalizados, despolitizados e fragmentados da realidade.

\section{ALGUMAS CONSIDERAÇÕES}

O momento histórico que "concluo" estes escritos não é dos mais favoráveis para a conjuntura mundial e, especialmente, para o Brasil. Como períodos de instabilidade costumam promover, também, maiores movimentos reflexivos, não pude deixar de me atentar em como as Tecnologias da Informação e Comunicação têm figurado um importante papel durante a pandemia da COVID-19, no ano de 2020, inscrevendo novas relações e novos sujeitos no ciberespaço.

Subitamente, com as medidas de isolamento social, conferimos mais do que nunca o alargamento do espaço privado na sociedade e, consequentemente, o encolhimento do espaço público. Os fluxos da globalização tiveram que ser freados drasticamente para evitar a disseminação rápida do vírus. As dinâmicas de trabalho, de educação, de consumo e de recreação tiveram que ser reformuladas ou interrompidas (mesmo que, no Brasil, houvesse certa resistência do atual presidente e seus apoiadores). Todavia, ao passo que muitas dinâmicas no mundo material foram cessadas, transferimos grande parte de nossas tarefas cotidianas para uma realidade cibernética.

Os fluxos das redes informacionais e comunicativas cresceram, indubitavelmente, quando analisamos a expansão da modalidade de home office por diversas empresas, o ensino a distância (EaD) via conferência por escolas e universidades e as defesas de monografias, dissertações e teses via Skype. A quarentena nos "impossibilitou" de manter contato próximo com nossos familiares e amigos, fez adquirirmos forçadamente o hábito - muito comum no Leste asiático - de se utilizar máscaras ao sair de casa (o que deveria ocorrer apenas quando era realmente necessário, como em idas ao supermercado). Escrevo todas essas alterações sobre nossos hábitos cotidianos em conjugação pretérita, no entanto, neste mesmo 
momento, ainda me encontro em quarentena dentro minha residência (que é, ironicamente, minha casa eletrônica).

Devemos tomar este contexto histórico como um objeto de questionamento sobre a notoriedade do ciberespaço num cenário de pandemia. Ao transferir nossas atividades para o mundo virtual, automaticamente transferimos nossos dados, de maneira ou outra. Professores que, por exemplo, nunca ministraram uma aula via Skype ou Zoom, durante o isolamento social, tiveram que baixar os aplicativos e criarem contas próprias, fornecendo suas informações pessoais, seus rostos e suas vozes a estes serviços. Mais drasticamente, na China e Coreia do Sul, por exemplo, foram adotadas medidas de controle do vírus a partir da obtenção estatal dos dados de empresas de telefonia e fornecedoras de Internet a respeito da localização de seus usuários nas ruas. Em Dubai, capital dos Emirados Árabes Unidos, os cidadãos só poderiam sair de suas casas através da emissão de um documento permissivo online, controlado pelo governo local, caso contrário, os que saíssem sem autorização oficial seriam multados em valores extraordinários ou até mesmo detidos.

No Brasil, arrisco dizer, ainda há maiores resistências no fornecimento de dados da população ao Estado. A título de exemplo, observamos a suspensão da medida provisória determinada pelo Supremo Tribunal Federal (STF) brasileiro, que impossibilitou o compartilhamento de dados de celular com IBGE para o monitoramento de aglomerações no país. Aqui, a concepção de privacidade ainda é bastante categórica, mas, curiosamente, pudemos observar mais de 93 milhões de brasileiros fornecerem seus dados ao requisitarem à Caixa Econômica Federal o Auxílio Emergencial disponibilizado pela União, como medida de diminuir os impactos econômicos àqueles que haviam sido afetados pela pandemia.

Neste momento não desejo chegar em conclusões, apenas exercitar reflexões. Como afirmam alguns ciberentusiastas neste contexto que descrevi, o big data pode ser um enorme instrumento de defesa na pandemia. Para que ele ganhe esse poder, o precisamos fornecer nossas próprias informações (como nossa localização, nossos gostos e nossos desejos) ao ciberespaço - ou, melhor dizendo, aos que gerenciam este instrumento. Um novo modelo é imposto na sociedade: é soberano quem detém dados. Desde as grandes corporações até o Estado, como eles ainda poderão atualizar o espaço geográfico a partir das tecnologias da informação e comunicação? Sem dúvidas, este é um dos maiores questionamentos da contemporaneidade. 


\section{REFERÊNCIAS}

BARBOSA, L. Sociedade de consumo. Rio de Janeiro: Jorge Zahar Ed., 2004. CASTELLS, M. A sociedade em rede. São Paulo: Paz e Terra, 1999. A galáxia da Internet: reflexões sobre Internet, negócios e sociedade. Lisboa: Fundação Calouste Gulbenkian, 2007. CHAUÍ, M. Simulacro e poder: uma análise da mídia. São Paulo: Editora Fundação Perseu Abramo, 2006. . Comunicação e democracia. PAULUS: Revista de Comunicação da FAPCOM, v. 1, n. 2, p. 15-32, 2017. Disponível em: <

https://fapcom.edu.br/revista/index.php/revista-paulus/article/view/21>. Acesso em: 06 jun. 2020.

DEBORD, G. Sociedade do espetáculo. Rio de Janeiro: Contraponto, 2000. DIAS, L.C. Redes: emergência e organização. In: CASTRO, I.E.; GOMES, P.C.C.; CORRÊA, R.L. (Orgs.). Geografia: conceitos e temas. Rio de Janeiro: Bertrand Brasil, 2007. p. 141-162.

DOUZET, F. La géopolitique pour comprendre le cyberespace. Hérodote, v. 152-153 n. 1, p. 3-21, 2014. Disponível em: <https://www.herodote.org/spip.php?article616>. Acesso em: 13 jul. 2020.

FERNANDES, S. Sintomas mórbidos: a encruzilhada da esquerda brasileira. São Paulo: Autonomia Literária, 2019. [Livro digital]. FREIRE, P. Pedagogia do Oprimido. Rio de Janeiro: Paz e Terra, 1987. GIBSON, W. Neuromancer. Nova Iorque: Ace Books, 1984.

HAIDER, A. A armadilha da identidade: raça e classe nos dias de hoje. São Paulo: Veneta, 2019. [Livro digital].

HARVEY, D. 17 contradições e o fim do capitalismo. São Paulo: Boitempo, 2017. [Livro digital].

ISRAEL, C.B. Redes digitais, espaços de poder: sobre conflitos na reconfiguração da Internet e as estratégias de apropriação civil. Tese (Doutorado em Geografia Humana) - Faculdade de Filosofia, Letras e Ciências Humanas, USP, São Paulo, 2019. Disponível em:

https://teses.usp.br/teses/disponiveis/8/8136/tde-24052019-102927/pt-br.php. Acesso em: 28 out. 2020.

LASCH, C. A cultura do narcisismo: a vida americana numa era de esperanças em declínio. Rio de Janeiro: Imago, 1983. 


\section{LEMOS, A. Cibercultura: tecnologia e vida social na cultura} contemporânea. Porto Alegre: Sulina, 2008.

LÉVY, P. A emergência do cyberspace e as mutações culturais. Palestra realizada no Festival Usina de Arte e Cultura, promovido pela Prefeitura Municipal de Porto Alegre, em outubro, 1994. Tradução: Suely Rolnik. Revisão: João Batista. Francisco e Carmem Oliveira. Disponível em:

< https://www.nescon.medicina.ufmg.br/biblioteca/imagem/2514.pdf > . Acesso em: O1 mai. 2020.

Cibercultura. São Paulo: Editora 34, 1999.

MARX, K. O capital: crítica da economia política. Livro 1: O processo de produção capitalista. Rio de Janeiro: Civilização Brasileira, 1971.

MARX, K; ENGELS, F. Manifesto do Partido Comunista. Lisboa: Edições Avante!, 1975 .

RAFFESTIN, C. Por uma geografia do poder. São Paulo: Ática, 1993.

RAMIRES, J.C.L. Pesquisa qualitativa dos espaços virtuais: algumas reflexões. In: PESSÔA, V.L.S. et al. (Orgs.). Pesquisa qualitativa: aplicações em geografia. Porto Alegre: Imprensa Livre, 2017. Disponível em: <

https://wp.ufpel.edu.br/leaa/files/2018/02/EBOOK_Pesquisa_PRONTO FINAL-12.pdf>. Acesso em: 25 out. 2019.

RANDOLPH, R. Tecnologias de informação e comunicação, redes de computadores e transformações socioespaciais contemporâneas. In: DIAS, L. C.; SILVEIRA, R. L. L. (Orgs.). Redes, sociedades e territórios. Santa Cruz do Sul: EDUNISC, 2005. RÜDIGER, F. As teorias da cibercultura: perspectivas, questões e autores. Porto Alegre: Sulina, 2011.

SANTOS, M. Técnica Espaço Tempo. Globalização e meio técnico-científico informacional. São Paulo: Hucitec, 1996.

Por uma outra globalização: do pensamento único à consciência universal. São Paulo: Record, 2000.

. Por uma geografia nova. São Paulo: EDUSP, 2012.

A natureza do espaço: Técnica e tempo. Razão e emoção. 4. ed. 9. reimpr. São Paulo: EDUSP, 2017.

WE ARE SOCIAL. Digital 2020: 3.8 billion people use social media.

Disponível em: <https://wearesocial.com/blog/2020/01/digital-2020-3-8-billionpeople-use-social-media >. Acesso em: o8 mai. 2020. 
WERTHEIM, M. Uma história do espaço de Dante à Internet. Rio de Janeiro: Jorge Zahar Ed., 2001.

WISNIK, G. Dentro do nevoeiro: diálogos cruzados entre arte e arquitetura contemporânea. Tese (Doutorado História e Fundamentos da Arquitetura e do Urbanismo), Faculdade de Arquitetura e Urbanismo, Universidade de São Paulo, 2012. 